\title{
PERBUATAN MELAWAN HUKUM MATERIIL MENURUT HAKIM PENGADILAN NEGERI KEPANJEN
}

\author{
Fakhruddin Arrozi \\ Sekolah Menengah Pertama Muhammadiyyah 2 Jl. Peneleh VI-72 Surabaya | \\ fakhruddin.feruzzi@gmail.com
}

\begin{abstract}
This paper describes the material tort against the decision of Pengadilan Negeri (PN) of Kepanjen No. 9//Pid.B/2008 / PN.KPJ on a post-verdict corruption of Constitutional Court of RI. No.003/PUUIV/2006 and then analyzes from the standpoint of positive law and criminal (jinayah) Jurisprudence. The study concludes that although a tort is legally no longer valid in law of Indonesia after the Constitutional Court's decision but in the case of corruption, Pengadilan Negeri of Kepanjen still applies the rule of the material tort. The existence of obscurity formula of tort is caused by the interpretation of the law and jurisprudence on tort material conducted by PN Kepanjen. The action of Pengadilan Negeri of Kepanjen in performing legal discovery and referring to jurisprudence, according to the criminal jurisprudence perspective, is true because Islam encourages its followers to do ijtihad when the rules are silent on the case submitted to the judge. If the judge cannot do ijtihad, he should refer to the previous jurisprudence.

Keywords: Law, material, corruption, jurisprudence.
\end{abstract}

Abstrak: Tulisan ini mendeskripsikan perbuatan melawan hukum materiil dalam putusan Pengadilan Negeri Kepanjen No. 9I/PID.B/2008/PN.KPJ tentang Tindak Pidana Korupsi pascaputusan Mahkamah Konstitusi RI. No.003/PUU-IV/2006 kemudian dianalisis dengan Fikih Jinayah. Hasil penelitian menyimpulkan bahwa walaupun secara legal formil perbuatan melawan hukum materiil sudah tidak berlaku lagi dalam kebijakan hukum di Indonesia setelah keluarnya putusan MK, namun dalam praktik peradilan tindak pidana korupsi, PN Kepanjen tetap menerapkan aturan perbuatan melawan hukum materiil. Adanya ketidak jelasan rumusan "sifat melawan hukum" disebabkan oleh kosongnya norma perbuatan melawan hukum materiil menyebabkan PN Kepanjen melakukan upaya penemuan 
hukum dengan penafsiran hukum dan juga merujuk kepada yurisprudensi yang ada tentang perbuatan melawan hukum materiil. Perspektif fikih jinayah, tindakan PN Kepanjen yang melakukan penemuan hukum dan merujuk pada yurisprudensi adalah benar, sebab Islam mengajarkan untuk melakukan ijtihad ketika peraturan tidak mengatur tentang kasus yang diajukan kepada hakim untuk diselesaikan. Apabila Hakim tidak bisa berijtihad, maka ia boleh merujuk kepada fatwa hakim yang terdahulu/yurisprudensi.

Kata Kunci: Hukum, Materiil, Korupsi, Fikih Jinayah.

\section{Pendahuluan}

Sifat melawan hukum merupakan sebuah problematika dalam ranah peradilan di Indonesia, khususnya dalam penanganan kasus tindak pidana korupsi. Sebab sifat melawan hukum dipahami dalam dua pengertian, yakni secara formil maupun materiil. Sebagaimana Penjelasan Pasal 2 ayat 1 UU No. 31 tahun 1999 Jo. UU No. 20 Tahun 2001 menjabarkan bahwa yang dimaksud dengan "secara melawan hukum" dalam pasal ini mencakup perbuatan melawan hukum dalam arti formil maupun dalam arti materiil, yakni meskipun perbuatan tersebut tidak diatur dalam peraturan perudang-undangan, namun apabila perbuatan tersebut dianggap tercela karena tidak sesuai dengan rasa keadilan atau norma-norma kehidupan sosial dalam masyarakat, maka perbuatan tersebut dapat dipidana. ${ }^{1}$

Mahkamah Konstitusi RI. menilai terdapat persoalan konstitusionalitas dalam kalimat pertama Penjelasan Pasal tersebut, sehingga pada tanggal 25 Juli 2006 dinyatakan bahwa Penjelasan Pasal tersebut bertentangan dengan UUD NRI 1945 dan tidak mempunyai kekuatan hukum mengikat. Dengan begitu sifat melawan hukum hanya diartikan dalam arti formil saja.

Kenyataannya, pascaputusan MK tersebut masih ada peradilan tindak pidana korupsi yang menggunakan arti materiil perbuatan melawan hukum pada praktik peradilannya. Hal ini nampak dalam konsiderans putusan Pengadilan Negeri (PN)

\footnotetext{
' Periksa Penjelasan Pasal 2 Ayat (I) UU No. 3 I tahun 1999 Jo. UU No. 20 Tahun 200 I.
}

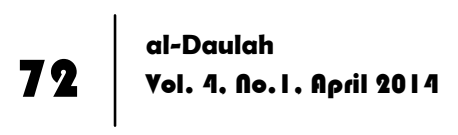


Kepanjen Nomor 91/PID.B/2008/PN.KPJ. dalam kasus korupsi Dana Pembangunan Desa atas nama terdakwa Abdul Mukti.

Tulisan ini menelusuri perbuatan melawan hukum materiil dalam putusan Pengadilan Negeri Kepanjen No. 91/PID.B/2008/PN.KPJ tentang Tindak Pidana Korupsi pascaputusan Mahkamah Konstitusi RI. No.003/PUU-IV/2006 ditinjau dari perspektif hukum positif dan fikih jinayah.

\section{Perbuatan Melawan Hukum Materiil Menurut Hukum Positif}

Pada tataran teori dan praktik, sifat melawan hukum dikenal baik dalam hukum perdata maupun dalam hukum pidana. Perbuatan melawan hukum dalam bahasa Belanda disebut dengan "wederrechtelijk" dalam lingkup pidana dan "onrechtmatige daad" dalam lingkup perdata. ${ }^{2}$ Sebelum tahun 1919 di negeri Belanda, sifat melawan hukum hanya diartikan sebagai pelanggaran dari pasal-pasal hukum yang tertulis saja (pelanggaran perundangundangan yang berlaku). Tetapi sejak tahun 1919, Belanda mengalami perkembangan hukum dengan mengartikan "melawan hukum" bukan hanya untuk pelanggaran perundang-undangan tertulis saja, melainkan juga untuk setiap pelanggaran terhadap kesusilaan atau kepantasan dalam pergaulan hidup masyarakat. Hal ini berdasarkan putusan Hoge Raad (H.R) atau Mahkamah Agung negeri Belanda tanggal 31 Januari 1919 dalam kasus Lindenbaum versus Cohen mengenai perkara perdata. ${ }^{3}$

Hukum pidana mulai mengenal sifat melawan hukum materiil (materiele wederrechtelijkheid) pada tanggal 20 Februari 1933 melalui putusan H.R dalam kasus dokter hewan dari kota Huzein. ${ }^{4}$ Sehingga sejak tahun 1933 konsep sifat melawan hukum dalam tindak pidana dapat dibagi menjadi dua macam yaitu:

2 Munir Fuady, Perbuatan Melawan Hukum (Pendekatan Kontemporer), (Bandung: PT Citra Aditya Bakti, 2005), 2.

${ }^{3}$ Ibid., 5-6.

${ }^{4}$ Moeljatno, Asas-Asas Hukum Pidana, (Jakarta: Rineka Cipta, 1993), 136. 
a. Sifat melawan hukum yang formil (formele wederrechtelijkheid)

Suatu perbuatan itu bersifat melawan hukum, apabila perbuatan diancam pidana dan dirumuskan sebagai suatu delik dalam undang-undang; sedang sifat melawan hukumnya perbuatan itu dapat hapus, hanya berdasarkan suatu ketentuan undang-undang. Jadi menurut ajaran ini melawan hukum sama dengan melawan atau bertentangan dengan undang-undang (hukum tertulis).

b. Sifat melawan hukum yang materiil (materiele wederrechtelijkheid)

Suatu perbuatan itu melawan hukum atau tidak, tidak hanya yang terdapat dalam undang-undang (yang tertulis) saja, akan tetapi harus dilihat berlakunya asas-asas hukum yang tidak tertulis. Sifat melawan hukumnya perbuatan yang nyata-nyata masuk dalam rumusan delik itu dapat hapus berdasarkan ketentuan undang-undang dan juga berdasarkan aturan-aturan yang tidak tertulis (uber gezetzlich). Menurut ajaran ini melawan hukum sama dengan bertentangan dengan undang-undang (hukum tertulis) dan juga bertentangan dengan hukum yang tidak tertulis termasuk tata susila. ${ }^{5}$

dibedakan:

Mengenai pengertian melawan hukum yang materiil dapat

a. Dalam fungsinya yang negatif

Ajaran sifat melawan hukum yang materiil dalam fungsinya yang negatif mengakui kemungkinan adanya halhal yang ada di luar undang-undang melawan hukumnya perbuatan yang memenuhi rumusan undang-undang, jadi hal tersebut sebagai alasan penghapus sifat melawan hukum.

b. Dalam fungsinya yang positif

Pengertian sifat melawan hukum yang materiil dalam fungsinya yang positif menganggap sesuatu perbuatan tetap

Kejaksaan Republik Indonesia, Asas-asas Hukum Pidana,
http://www.kejaksaan.go.id/pusdiklat/uplimg/File/Asas-asas\%20Hukum\%20Pidana.doc
31 Oktober 20 I3.


sebagai sesuatu delik, meskipun tidak nyata diancam dengan pidana dalam undang-undang, apabila bertentangan dengan hukum atau ukuran-ukuran lain yang ada di luar undangundang. Jadi di sini diakui hukum yang tak tertulis sebagai sumber hukum yang positif. ${ }^{6}$

\section{Perbuatan Melawan Hukum Materiil Menurut Hukum Islam}

Dalam fikih jinayah tidak ditemukan istilah yang baku tentang sifat melawan hukum materiil. Meskipun demikian, pada prinsipnya fikih jinayah mempertimbangkan pula asas-asas hukum yang tidak tertulis atau adat-tradisi sebagai landasan hukumnya jika memang nas tidak mengatur suatu perbuatan pidana. Adat atau 'urf adalah sesuatu yang telah berlaku di kalangan kaum muslimin baik berupa perkataan atau perbuatan yang tidak bertentangan dengan Alquran dan Sunnah; tidak menimbulkan kemafsadatan dan tidak menghilangkan kemaslahatan; dan tidak menimbulkan kesulitan. Kebolehan menggunakan adat sebagai landasan hukum didasarkan atas nas berikut:

1. Firman Allah dalam surah al-A'raf ayat 199:

"Jadilah engkau pema'af dan suruhlah orang mengerjakan yang ma'ruf, serta berpalinglah daripada orang-orang yang bodoh". ${ }^{7}$

2. Perkataan 'Abdullah bin Mas'ud r.a.:

"Apa yang dipandang baik oleh kaum muslimin, baik pula menurut pandangan Allah dan apa yang dipandang jelek oleh kaum muslimin, jelek pula menurut pandangan Allah". ${ }^{8}$

Jaih Mubarok mengutip pendapat Muhammad Abu Zahrah tentang perkataan Abdullah bin Mas'ud di atas bahwa baik dari segi pengungkapannya maupun dari segi tujuannya menunjukkan bahwa setiap perkara yang telah mentradisi di kalangan kaum

7 Yayasan Penyelenggara Penterjemah/Penafsir Alquran, Alquran dan Terjemahnya, (Jakarta: Yayasan Penyelenggara Penterjemah/Penafsir Alquran, 197I), 255.

${ }^{8}$ Jaih Mubarok, Kaidah Fiqh Jinayah Asas-asas Hukum Pidana Islam, (Bandung: Pustaka Bani Quraisy, 2004), I I - I I2.
} 
muslimin dan dipandang sebagai perkara yang baik, maka perkara tersebut dipandang baik pula oleh Allah. Oleh karena itu, ulama Hanafiyah dan Malikiyah menyatakan bahwa hukum yang ditetapkan berdasarkan adat atau 'urf yang baik sama dengan yang ditetapkan berdasarkan dalil syarak. Sedangkan ulama Syafi'iyah menyatakan bahwa hukum yang ditetapkan oleh 'urf yang baik sama dengan yang ditetapkan oleh nas, sehingga para ulama sepakat menyusun sebuah kaidah asasi yang berkenaan

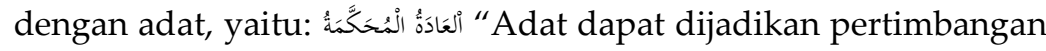
dalam penetapan hukum". ${ }^{9}$

Dengan begitu dapat diambil kesimpulan bahwa hukum pidana Islam juga mempertimbangkan asas-asas di luar hukum tertulis dengan menggunakan 'urf dalam pertimbangan hukumnya. Meskipun suatu perbuatan tersebut tidak diatur dalam nas, namun apabila perbuatan tersebut dianggap tercela karena tidak sesuai dengan rasa keadilan masyarakat, maka perbuatan tersebut dapat dipidana. Suatu perbuatan melanggar pun dapat dihapuskan jika itu tidak dianggap tercela. Sebagaimana perkataan Abdullah bin Mas'ud di atas, dapat kita katakan bahwa jika kaum muslimin menganggap suatu perkara / perbuatan baik maka Allah juga akan menganggapnya baik, namun jika kaum muslimin mengganggap tercela suatu perbuatan maka Allah akan menganggapnya tercela pula, sehingga hukuman pidana bisa dijatuhkan kepadanya. Dan ada hadis yang terkenal menyebutkan,

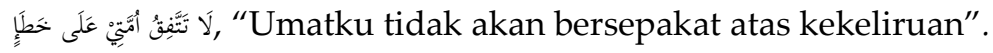

\section{Perbuatan Melawan Hukum Materiil Menurut Hakim Pengadilan Negeri Kepanjen}

Dalam konsiderans Putusan Pengadilan Negeri Kepanjen No. 91/PID.B/2008/PN.KPJ, majelis hakim menyatakan:

Menimbang, bahwa pengertian "Melawan Hukum" adalah dalam pengertian formil maupun materiil dimana ajaran sifat

${ }^{9}$ Ibid., I |2- | 13. 
melawan hukum yang formal mengatakan bahwa apabila suatu perbuatan telah mencocoki semua unsur yang termuat dalam rumusan tindak pidana, perbuatan tersebut adalah tindak pidana dan ajaran yang materiil mengatakan bahwa di samping memenuhi syarat-syarat formal, yaitu mencocoki semua unsur yang tercantum dalam rumusan delik, perbuatan itu harus benarbenar dirasakan oleh masyarakat sebagai perbuatan yang tidak patut atau tercela;

Menimbang, bahwa sifat melawan hukum formal berarti semua bagian (tertulis dalam undang-undang) dari rumusan delik telah terpenuhi dan sifat melawan hukum materiel berarti bahwa karena perbuatan itu, kepentingan hukum yang dilindungi oleh rumusan delik tertentu telah dilanggar;

Menimbang, bahwa Profesor Van Hattum mengatakan bahwa: "menurut ajaran wederrechtelijkheid dalam arti formal suatu perbuatan hanya dapat dipandang sebagai bersifat wederrechtelijk apabila perbuatan tersebut memenuhi semua unsur yang terdapat di dalam rumusan suatu delik menurut undang-undang dan menurut ajaran wederrechtelijkheid dalam arti material, apakah suatu perbuatan itu dapat dipandang sebagai bersifat wederrechtelijk atau tidak, masalahnya bukan saja harus ditinjau sesuai dengan ketentuan-ketentuan hukum yang tertulis, melainkan juga harus ditinjau menurut asas-asas hukum umum dari hukum yang tidak tertulis";

Menimbang, bahwa dalam praktik peradilan khususnya melalui perkembangan yurisprudensi pengertian "melawan hukum" terjadi pergeseran dari perbuatan melawan hukum materiil dengan fungsi positif dan negatif dimana fungsi negatif sebagai alasan peniadaan pidana guna menghindari pelanggaran asas legalitas maupun penggunaan analogi yang dilarang oleh hukum pidana sedangkan pergeseran perbuatan melawan hukum materiil ke arah fungsi positif melalui kretaria limitatif dan kasuistik berupa perbuatan pelaku yang tidak memenuhi rumusan delik dipandang dari segi kepentingan hukum yang lebih tinggi ternyata 
menimbulkan kerugian yang jauh tidak seimbang bagi masyarakat/negara dibandingkan dengan keuntungan dari perbuatan pelaku yang tidak memenuhi rumusan delik tersebut ;

Menimbang, bahwa dalam Putusan Mahkamah Konstitusi Nomor: 003/PUU-IV/2006 tanggal 25 Juli 2006 menyatakan penjelasan ketentuan Pasal 2 ayat (1) UU Nomor 31 Tahun 1999 jo UU Nomor 20 Tahun 2001 yang mengatur perbuatan melawan hukum materiil bertentangan dengan UUD 1945 dan telah pula dinyatakan tidak mempunyai kekuatan hukum mengikat;

Menimbang, bahwa pasca Putusan Mahkamah Konstitusi Nomor: 003/PUU- IV/2006 tanggal 25 Juli 2006 Mahkamah Agung dalam beberapa putusannya (Putusan Mahkamah Agung Nomor $996 \mathrm{~K} / \mathrm{Pid} / 2006$ tanggal 16 Agustus 2006 atas nama terdakwa Hamdani Amin dan Putusan Mahkamah Agung RI Nomor 1974 K/Pid/2006 tanggal 13 Oktober 2006 atas nama terdakwa Prof. Dr. Rusadi Kantaprawira SH.) tetap menerapkan ajaran perbuatan melawan hukum materiil sebagaimana ketentuan Pasal 2 ayat (1) UU Nomor 31 Tahun 1999 jo UU Nomor 20 Tahun 2001 dengan alasan-alasan sebagai berikut:

1. Pasca Putusan Mahkamah Konstitusi Nomor 003/PUU-IV/2006 tanggal 25 Juli 2006 khususnya terhadap eksistensi ketentuan Pasal 2 ayat (1) UU Nomor 31 Tahun 1999 jo UU Nomor 20 Tahun 2001 dinyatakan bertentangan dengan UUD 1945 dan tidak mempunyai kekuatan hukum mengikat, maka yang dimaksud dengan unsur "melawan hukum" menjadi tidak jelas rumusannya. Oleh karena itu berdasarkan doktrin "Sens-Clair" (la doctrine $d u$ senclair) hakim harus melakukan penemuan hukum dengan memperhatikan ketentuan Pasal 28 ayat (1) UU Nomor 4 Tahun 2004 yang menentukan, "Hakim wajib menggali, mengikuti dan memahami nilai-nilai hukum dan rasa keadilan yang hidup dalam masyarakat", karena menurut ketentuan Pasal 16 ayat (1) UU Nomor 4 Tahun 2004, "Pengadilan tidak boleh menolak untuk memeriksa, mengadili dan memutus suatu perkara yang diajukan dengan dalih bahwa hukum tidak ada atau kurang 
jelas, melainkan wajib memeriksa dan mengadilinya". Selain itu juga Hakim dalam mencari makna "melawan hukum" seharusnya mencari dan menemukan kehendak publik yang bersifat unsur pada saat ketentuan tersebut diberlakukan pada kasus kongkrit. Tegasnya, sebagaimana disebutkan Hamaker bahwa hakim seyogianya mendasarkan putusannya sesuai dengan kesadaran hukum dan penerapan hukum yang sedang hidup di dalam masyarakatnya ketika putusan itu dijatuhkan, oleh karena itu menurut I.H. Hymans hanya putusan hukum yang sesuai dengan kesadaran hukum dan kebutuhan hukum warga masyarakatnya yang merupakan "hukum dalam makna sebenarnya". Konklusi dasarnya, sebagaimana dikatakan Lie Oen Hock bahwa, "apabila kita memperhatikan UU, ternyata bagi kita bahwa UU tidak saja menunjukan banyak kekurangan-kekurangan, tapi seringkali juga tidak jelas. Walaupun demikian hakim harus melakukan peradilan. Teranglah, bahwa dalam hal sedemikian UU memberi kuasa kepada hakim untuk menetapkan sendiri maknanya ketentuan UU itu atau artinya suatu kata yang tidak jelas dalam suatu ketentuan UU. Dan hakim boleh menafsir suatu ketentuan UU secara gramatikal atau historis baik "rechts maupun wetshistoris", secara sistimatis atau secara sosiologis atau dengan cara memperbandingkan hukum.

2. Mahkamah Agung dalam memberi makna unsur "secara melawan hukum" dalam Pasal 2 ayat (1) UU Nomor 31 Tahun 1999 jo UU Nomor 20 Tahun 2001 memperhatikan doktrin dan Yurispudensi Mahkamah Agung RI yang berpendapat bahwa unsur "secara melawan hukum" dalam tindak pidana korupsi adalah mencakup perbuatan melawan hukum dalam arti formil maupun dalam arti materiil dan mengenai perbuatan melawan hukum dalam fungsi positif dan negatifnya, yang pengertiannya Mahkamah Agung berpedoman pada :

- Bahwa "Tujuan diperluasnya unsur perbuatan "melawan hukum", yang tidak saja dalam pengertian formil, namun 
meliputi perbuatan melawan hukum secara materiil, adalah untuk mempermudah pembuktiannya di persidangan, sehingga suatu perbuatan yang dipandang oleh masyarakat sebagai melawan hukum secara materiil atau tercela perbuatannya, dapatlah pelaku dihukum melakukan tindak pidana korupsi, meskipun perbuatannya itu tidak melawan hukum secara formil.

- Bahwa berdasarkan pengertian melawan hukum menurut Pasal 1 ayat (1) sub a UU Nomor 3 Tahun 1971, tidak hanya melanggar peraturan yang ada sanksinya melainkan mencakup pula perbuatan yang bertentangan dengan keharusan atau kepatutan dalam pergaulan masyarakat atau dipandang tercela oleh masyarakat.

- Bahwa dari butir 2 Surat Menteri Kehakiman RI tanggal 11 Juli 1970 sebagai pengantar diajukannya RUU Nomor 3 Tahun 1971 dapat disimpulkan pengertian perbuatan melawan hukum secara materiil adalah dititikberatkan pada pengertian yang diperoleh dari hukum tidak tertulis, hal ini tersirat dari surat tersebut yang pada pokoknya berbunyi, "Maka untuk mencakup perbuatan-perbuatan yang sesungguhnya bersifat koruptif akan tetapi sukar dipidana, karena tidak didahului suatu kejahatan atau pelanggaran dalam RUU ini dikemukakan saran "melawan hukum" dalam rumusan tindak pidana korupsi, yang pengertiannya juga meliputi perbuatan-perbuatan yang bertentangan dengan norma-norma yang lazim atau yang bertentangan dengan keharusan dalam pergaulan hidup untuk bertindak cermat terhadap orang lain, barang maupun haknya".

- Bahwa sejalan dengan politik hukum untuk memberantas korupsi dalam Putusan Mahkamah Agung RI tanggal 29 Desember 1983 Nomor 275 K/Pid/1983, untuk pertama kalinya dinyatakan secara tegas bahwa korupsi secara materiil melawan hukum, karena perbuatan tersebut adalah perbuatan yang tidak patut, tercela dan menusuk perasaan hati masyarakat banyak, dengan memakai tolok ukur asas- 
asas hukum yang bersifat umum menurut kepatutan dalam masyarakat.

- Bahwa yurisprudensi dan doktrin merupakan sumber hukum formil selain UU dan kebiasaan serta traktat yang dapat digunakan oleh Mahkamah Agung dalam kasus kongkrit yang dihadapinya, yurisprudensi tentang makna perbuatan melawan hukum dalam arti formil dan dalam arti materiil harus tetap dijadikan pedoman untuk terbinanya konsistensi penerapannya dalam perkara-perkara tindak pidana korupsi, karena sudah sesuai dengan kesadaran hukum dan perasaan hukum yang sedang hidup dalam masyarakat, kebutuhan hukum warga masyarakat, nilainilai hukum dan rasa keadilan yang hidup dalam masyarakat.

Menimbang, bahwa berdasarkan pertimbanganpertimbangan sebagaimana tersebut di atas maka majelis hakim dalam mengadili perkara ini tetap menerapkan ajaran perbuatan melawan hukum materiil walaupun dalam Putusan Mahkamah Konstitusi Nomor: 003/PUU-IV/2006 tanggal 25 Juli 2006 perbuatan melawan hukum materiil sebagaimana ketentuan Pasal 2 ayat (1) UU Nomor 31 Tahun 1999 jo UU Nomor 20 Tahun 2001 dinyatakan bertentangan dengan UUD 1945 dan tidak mempunyai kekuatan hukum mengikat.

Analisis Fikih Jinayah terhadap Pertimbangan Hukum Hakim Pengadilan Negeri Kepanjen terhadap Perbuatan Melawan Hukum Materiil

Mahkamah Konstitusi berpendirian bahwa konsep melawan hukum materiil yang bersandar pada hukum tidak tertulis dalam ukuran kepatutan, kehati-hatian dan kecermatan yang hidup dalam masyarakat, sebagai satu norma keadilan, adalah merupakan ukuran yang tidak pasti, dan berbeda-beda dari satu lingkungan masyarakat tertentu kelingkungan masyarakat 
lainnya, sehingga apa yang melawan hukum di satu tempat mungkin di tempat lain diterima dan diakui sebagai sesuatu yang sah dan tidak melawan hukum. Akhirnya pada tanggal $25 \mathrm{Juli}$ 2006, Mahkamah konstitusi memutus bahwa perbuatan melawan hukum materiil tidak dapat diberlakukan di Indonesia.

Konsekuensinya, hal tersebut dapat mengakibatkan eksistensi perbuatan melawan hukum materiil hilang dalam kebijakan hukum di peradilan dan tidak akan ada hukuman terhadap tindak pidana korupsi yang tidak di tentukan terlebih dahulu di dalam UU. Meski demikian, kenyataannya Pengadilan Negeri Kepanjen tetap menerapkan perbuatan melawan hukum materiil dalam praktik peradilannya dan mengabaikan putusan MK tersebut, sebagaimana tertuang dalam konsiderans Putusan Pengadilan Negeri Kepanjen No. 91/PID.B/2008/PN.KPJ Tentang Tindak Pidana Korupsi.

PN Kepanjen yang sejalan dengan Mahkamah Agung, beranggapan bahwa setelah diputuskan bertentangan dengan UUD NRI 1945 dan tidak mengikat secara hukum, maka "melawan hukum" menjadi tidak jelas rumusannya, sehingga berdasarkan doktrin "Sens-Clair" (la doctrine du senclair) hakim harus melakukan penemuan hukum dengan memperhatikan ketentuan Pasal 28 ayat (1) UU Nomor 4 Tahun 2004 yang menentukan, "Hakim wajib menggali, mengikuti dan memahami nilainilai hukum dan rasa keadilan yang hidup dalam masyarakat", karena menurut ketentuan Pasal 16 ayat (1) UU Nomor 4 Tahun 2004, "Pengadilan tidak boleh menolak untuk memeriksa, mengadili dan memutus suatu perkara yang diajukan dengan dalih bahwa hukum tidak ada atau kurang jelas, melainkan wajib memeriksa dan mengadilinya". Selain itu juga hakim dalam mencari makna "melawan hukum" seharusnya mencari dan menemukan kehendak publik yang bersifat unsur pada saat ketentuan tersebut diberlakukan pada kasus kongkrit. Hakim seharusnya mendasarkan putusannya sesuai dengan kesadaran hukum dan penerapan hukum yang sedang hidup di dalam masyarakatnya ketika putusan itu 
dijatuhkan. Apabila diperhatikan, ternyata UU tidak saja menunjukan banyak kekurangan, tapi seringkali juga tidak jelas. Walaupun demikian hakim harus melakukan peradilan. Teranglah, bahwa dalam hal sedemikian UU memberi kuasa kepada hakim untuk menetapkan sendiri maknanya ketentuan UU itu atau artinya suatu kata yang tidak jelas dalam suatu ketentuan UU. Dan hakim boleh menafsir suatu ketentuan UU secara gramatikal atau historis baik "rechts maupun wetshistoris", secara sistimatis atau secara sosiologis atau dengan cara memperbandingkan hukum. Di samping itu PN Kepanjen juga masih berpegangan kepada yurisprudensi dan doktrin yang mengartikan perbuatan melawan hukum dalam arti formil dan materiil.

Penulis sependapat mengenai hal di atas yang mengatakan bahwa rumusan "melawan hukum" akan menjadi tidak jelas, setelah diputuskan bertentangan dengan UUD NRI 1945 dan tidak mengikat secara hukum, sehingga harus dilakukan penemuan hukum. Setelah MK memutus bahwa sifat perbuatan melawan hukum materiil tidak dapat diberlakukan di Indonesia, hal ini menyebabkan adanya kekosongan norma hukum terhadap perbuatan melawan hukum materiil dalam UU tipikor. Dengan demikian ketika ada kasus dengan sifat melawan hukum materiil, hakim berhak untuk mengisi kekosongan norma hukum itu dalam taraf yudisial, bukan legislasi yang notabene merupakan hak badan legislatif.

Berbeda halnya dengan badan legislatif yang menetapkan peraturan sebagai peraturan umum yang mempunyai kekuatan hukum universal, sedangkan keputusan hakim tidak mempunyai kekuatan hukum yang berlaku seperti peraturan umum, karena hanya berlaku terhadap pihak-pihak yang bersangkutan. Sebab hakim adalah pemegang kekuasaan yudikatif yang melakukan pertimbangan dalam pelaksanaan hal-hal yang kongkrit. ${ }^{10}$ 
Ketika seorang hakim dihadapkan dengan kasus korupsi yang tidak ada ketentuannya dalam UU tipikor dan kasus itu adalah perbuatan tercela yang menusuk rasa keadilan dalam masyarakat, maka tidak ada alasan bagi hakim untuk menolak kasus tersebut dan hakim berkewajiban untuk menafsirkannya sehingga dapat diberikan keputusan yang benar-benar adil dan sesuai dengan maksud hukum, yakni mencapai kepastian hukum dan keadilan. Untuk memberikan putusan yang seadil-adilnya penulis berpendapat bahwa hakim harus mengingat pula adatkebiasaan, yurisprudensi, ilmu pengetahuan dan akhirnya pendapat hakim sendiri ikut menentukan, sehingga perlu diadakan penafsiran hukum baik secara gramatikal atau historis baik "rechts maupun wetshistoris", secara sistimatis atau secara sosiologis atau dengan cara memperbandingkan hukum. Seorang hakim harus menentukan mana yang merupakan hukum dan yang tidak. Sebagaimana Paul Scholten yang mengatakan bahwa hakim itu menjalankan rechtsvinding (turut serta menemukan hukum) dalam hal peraturan perundang-undangan tidak menyebutkan suatu ketentuan untuk menyelesaikan suatu perkara yang terjadi. ${ }^{11}$

Keputusan PN Kepanjen yang menjadikan yurisprudensi atau keputusan-keputusan hakim yang terdahulu dan doktrin sebagai sumber hukum sudah tepat. Karena yurisprudensi dan doktrin merupakan sumber hukum formil selain UU (statute) dan kebiasaan (costum) serta traktat (treaty) yang dapat digunakan oleh hakim dalam kasus kongkrit yang dihadapi. Dan seorang hakim mengikuti keputusan hakim yang terdahulu itu karena sependapat dengan isi keputusan tersebut dan lagi pula hanya dipakai sebagai pedoman dalam mengambil suatu keputusan mengenai suatu perkara yang serupa.

Menilik beberapa alasan yang disebutkan MK, dapat diketahui bahwa penghapusan perbuatan melawan hukum materiil pada UU tipikor adalah untuk tegaknya kepastian hukum.

11 Ibid., 36. 
Sedangkan PN Kepanjen tetap menerapkannya adalah untuk pemenuhan rasa keadilan. Prinsip kepastian hukum dan keadilan ada dalam konsepsi negara hukum. Prinsip kepastian hukum lebih menonjol di dalam tradisi kawasan Eropa Kontinental dengan konsep negara hukum rechtstaat ${ }^{12}$, sedangkan rasa keadilan lebih menonjol di dalam tradisi hukum kawasan Anglo Saxon dengan konsep negara hukum the rule of law. ${ }^{13}$

Kenyataannya, dalam sistem peradilan kita kedua konsepsi negara hukum di atas sama-sama digunakan. Hal itu dapat dibuktikan dengan diberlakukannya asas legalitas sebagaimana tercantum dalam pasal 1 ayat (1) KUHP yang di dalamnya terdapat prinsip kepastian hukum. Dan juga Putusan Mahkamah Agung RI Nomor: 42 K/Kr/1965 jo. Putusan Mahkamah Agung RI Nomor: 275 K/Pid/1982 yang menerapkan norma-norma berdasarkan asas-asas hukum yang tidak tertulis, maupun asasasas yang bersifat umum menurut kepatutan dalam masyarakat.

Menurut Mahfud M.D, atas alasan kepastian hukum, pada masa lampau banyak terjadi manipulasi dengan menggunakan bukti-bukti formal yang digunakan dalam berbagai kasus sehingga formalitas-formalitas sering dijadikan alat pemutihan bagi pelaku tindak pidana, terutama dalam kasus korupsi. Alasan yang digunakan untuk itu adalah konsep negara hukum rechtstaat sebagaimana tertuang dalam penjelasan UUD NRI 1945 sebelum amandemen. Dengan adanya istilah rechtstaat, sering dilakukan manipulasi dengan mengatakan bahwa UUD NRI 1945 hanya

12 Konsep negara hukum Eropa Kontinental rechtstaat dipelopori oleh Immanuel Kant dan Federich Julius Stahl. Menurut Stahl konsep ini ditandai oleh empat unsur pokok: I) pengakuan dan perlindungan terhadap hak asasi manusia; 2) negara didasarkan pada teori trias politika; 3) pemerintahan diselenggarakan berdasarkan undang-undang (wetmatig bertuur); dan 4) ada peradilan administrasi negara yang bertugas menangani kasus perbuatan melanggar hukum oleh pemerintah (onrechtmatige overheidsdaad). Titik Triwulan Tutik, Konstruksi Hukum Tata Negara Indonesia Pasca Amandemen UUD 1945, (Jakarta: Kencana, 20 I0), 61.

13 Konsep negara hukum Anglo-Saxon rule of law dipelopori oleh A.V. Dicey. Menurutnya, konsep ini menekankan pada tiga tolok ukur: I) supremasi hukum (supremacy of law); 2) persamaan di hadapan hukum (equality before the law); 3) konstitusi yang didasarkan atas hakhak perorangan (the constitution based on individual rights). Moh. Mahfud M.D., "Dilema Sifat Melawan Hukum (I) Kepastian Hukum atau Keadilan?", Jawa Pos, (08 September 2006).

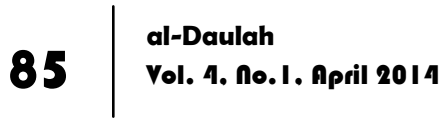


menghendaki kepastian hukum dan tidak menghendaki keadilan yang sulit diukur secara formal. Lalu, melalui amandemen UUD NRI 1945 yang meniadakan penjelasan, konsepsi negara hukum Indonesia kemudian dicantumkan pada pasal 1 ayat (3) yang menyebutkan bahwa Indonesia adalah negara hukum, tanpa embelembel rechtstaat maupun the rule of law. Perumusan tanpa embelembel itu sebenarnya dilakukan dengan sengaja (bukan sekedar penyederhanaan semantik) dengan maksud untuk memberi ruang yang lebih luas pada pemenuhan rasa keadilan tanpa dominasi kepastian hukum dan formalitas. ${ }^{14}$

Menurut hukum Islam, penerapan perbuatan melawan hukum materiil dalam praktik peradilan tindak pidana korupsi setelah ada putusan MK adalah wajib, meskipun dalam UU tidak ditemukan peraturan yang mengatur sifat melawan hukum materiil lagi. Hakim harus berusaha untuk mencapai suatu putusan tentang kasus yang penyelesaiannya belum tertera dalam peraturan demi tercapainya keadilan. Dalam istilah Islam kegiatan seperti ini disebut ijtihad.15 Namun ijtihad ini sebenarnya

14 Moh. Mahfud M.D., "Dilema Sifat Melawan Hukum (2-Habis) Kepastian Hukum Tabrak Keadilan", Jawa Pos, 09 September 2006.

15 ljtihad menurut istilah ulama fikih adalah mencurahkan tenaga untuk mengambil kesimpulan hukum-hukum dari dasar-dasarnya, dengan penelitian yang dapat menyampaikan kepada tujuan itu. Mujtahid disyaratkan harus cerdas, baligh, dan adil, mengetahui hukum-hukum Alquran, dan Sunnah, mengetahui hukum-hukum yang diijma'i ulama dan yang diperselisihkan di antara mereka, mengetahui cacat-cacat hukum, jalan-jalannya, cara-cara mengambil kesimpulan dari dalil-dalii, dan segi-segi petunjuk lafal-lafal atas makna-maknanya, dan mengetahui ilmu bahasa dengan ukuran mampu memahami nas dengan benar. Muhammad Salam Madkur, Al-Qada' Fi al-Islam, (Surabaya: Bina IImu, t.t.), I58-160.). Dasar hukum ïtihad ada dalam Alquran dan Sunah. Di antara ayat-ayat Alquran yang dijadikan dasar adalah firman Allah swt. dalam surah al Nisa'(4) ayat 105 yang artinya: "Sesungguhnya kami telah menurunkan Kitab kepadamu dengan membawa kebenaran, supaya kamu mengadili antara manusia dengan apa yang telah diwahyukan kepadamu...". Adapun dasar hukum ijtihad dalam sunah adalah hadis yang intinya menceritakan dialog Rasulullah saw. dengan Mu'az bin Jabal; salah seorang sahabat ketika diutus ke Yaman sebagai hakim. Pada waktu itu Rasulullah saw. bertanya kepadanya tentang cara menetapkan hukum apabila ada kasus yang dihadapkan kepadanya. Mu'az mengatakan: "Apabila saya dapati dalam Alquran maka saya terapkan ayat itu; apabila tidak ada dalam Alquran, saya cari dalam sunah Rasulullah saw.; dan apabila dalam sunah Rasulullah saw. juga tidak ada hukumnya maka saya akan berijtihad" (HR. Abu Dawud, al-Tirmizi, dan al-Darimi). Abdul Aziz Dahlan, (et al), Ensiklopedi Hukum Islam, Jilid II, (Jakarta: Ichtiar Baru Van Hoeve, 2003), 669670.

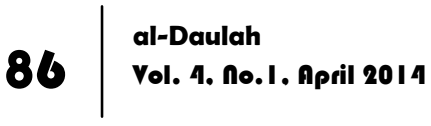


diterapkan untuk suatu perkara yang penyelesaiannya belum tertera dalam Alquran dan Sunah Rasulullah saw., dan ini lapangannya sangat sempit untuk diterapkan di negara-negara yang mempunyai undang-undang wad'iyyah (undang-undang buatan manusia) yang telah dikodifisir. Meskipun demikian, mengacu kepada disyariatkannya ijtihad tersebut, sudah selayaknya hakim melakukan penemuan hukum terhadap suatu perkara yang tidak ada penyelesaiannya dalam peraturan perundang-undangan untuk mendapatkan maslahah (al-ijtihad alistislah), ${ }^{16}$ dengan metode yang bermacam-macam seperti istihsan, istislah dan 'urf. Namun dalam masalah ini (perbuatan melawan hukum materiil) tampaknya metode 'urf lah yang tepat untuk digunakan sebagai dasar berijtihad, yakni upaya mujtahid dalam menetapkan hukum melalui perkembangan adat istiadat yang berlaku di suatu masyarakat, baik menyangkut perkataan maupun perbuatan, baik adat itu bersifat umum untuk mayoritas manusia di berbagai wilayah maupun berlaku khusus dalam masyarakat tertentu.

Hakim tidak boleh menolak suatu perkara yang diajukan untuk dimintai penyelesaian, sebagaimana firman Allah swt. dalam surah Shad ayat 26:

"Hai Daud, sesungguhnya Kami menjadikan kamu khalifah (penguasa) di muka bumi, maka berilah keputusan (perkara) di antara manusia dengan adil dan jangalah kamu mengikuti hawa nafsu, karena ia akan menyesatkan kamu dari jalan Allah. Sesungguhnya orang-orang yang sesat dari jalan Allah akan mendapat azab yang berat, karena mereka melupakan hari perhitungan."17

Sebagaimana halnya dengan keputusan hakim yang hanya mengikat kepada pihak-pihak yang berperkara atau perkara-

\footnotetext{
${ }^{16}$ Al-ijtihad al-istislahi adalah ïtihad dengan menggunakan penalaran sesuai prinsip kemaslahatan, merupakan salah satu metode ïtihad hasil rumusan al-Duwailibi. Rumusan lainnya adalah alïtihad al-bayaniy dan al-ijtihad al-qiyasiy. Abd. Rahman Dahlan, Ushul Fiqh, (Jakarta: Amzah, 2010), 347-349.

${ }^{17}$ Yayasan Penyelenggara Penterjemah/Penafsir Alquran, Alquran Dan Terjemahnya, 736.
}

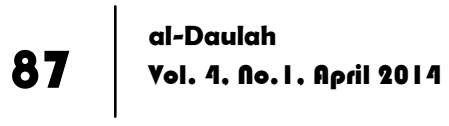


perkara tertentu, hasil ijtihad pun tidaklah merupakan hujjah dasar untuk semua perkara, karena hukum hasil ijtihad itu didasarkan atas sangkaan (zann). ${ }^{18}$

Apabila hakim tersebut tidak bisa berijtihad, dalam Islam ia diwajibkan untuk mengikuti pendapat mujtahid dan fatwanya untuk dijadikan hujjah baginya. Hal yang demikian biasa disebut ittiba'.19 Dalam hukum positif, fatwa dan pendapat mujtahid ini dapat disebut yurisprudensi (putusan hakim yang terdahulu). Dengan demikian, tindakan PN Kepanjen yang menjadikan yurisprudensi atau keputusan-keputusan hakim yang terdahulu dan doktrin sebagai sumber hukum sudah tepat menurut Islam.

Praktik penemuan hukum untuk aturan perbuatan melawan hukum materiil dan pengambilan yurisprudensi tentang doktrin tersebut sebagai sumber hukum yang dilakukan PN Kepanjen bisa dikatakan sebagai sebuah penguatan keputusan MA yang terdahulu. Hal ini sejalan dengan praktik ijtihad dalam Islam yang adakalanya dilakukan dengan cara mentarjih (menguatkan) hasil ijtihad sebelumnya, dan adakalanya seorang mujtahid melakukan ijtihad dengan menerapkan hukum ijtihad yang sudah ada. ${ }^{20}$

Secara keseluruhan praktik yang dilakukan oleh PN Kepanjen sudah tepat. Bahwa perbuatan melawan hukum materiil perlu untuk tetap diterapkan dalam ranah peradilan, khususnya dalam kasus korupsi. Selain untuk alasan pemenuhan rasa keadilan, ${ }^{21}$

${ }^{18}$ Muhammad Salam Madkur, A/ Qada' Fial-Islam, 161.

19 Ittiba', yakni mengambil suatu pendapat orang lain dengan mengetahui dasar atau dalilnya, sebab pada dasarnya pengambilan itu dari dalil dan bukan dari mujtahid itu sendiri, karena mengetahui dali itu merupakan tuntutan syarat ijtihad, sebab mengetahui benarnya dalil itu berkaitan juga dengan pengetahuan tentang dalil yang menentangnya. Ibid., 167.

${ }^{20}$ Abdul Aziz Dahlan, (et al), Ensiklopedi Hukum Islam, Jilid II, 672.

21 Sesungguhnya keadilan itu merupakan salah satu dari nilai-nilai Islam yang tinggi. Hal itu disebabkan menegakkan keadilan dan kebenaran menebarkan ketentraman, meratakan keamanan, memperkuat hubungan-hubungan antara individu dengan individu lain, memperkokoh kepercayaan antara penguasa dan rakyat, menumbuhkan kekayaan, menambahkan kesejahteraan dan meneguhkan tradisi, sehingga tradisi itu tidak mengalami kerusakan atau kekacauan. Sesungguhnya keadilan itu dapat diwujudkan dengan menyampaikan setiap hak kepada yang berhak dan dengan melaksanakan hukum-hukum yang telah disyariatkan Allah serrta dengan menjauhkan hawa nafsu melalui pembagian yang adil di antara manusia. Al Sayyid Sabiq, Fiqhussunnah, (Egypt: Dar Al-Fathi li Al-l'lamiAl-Araby, 1990), 214. 
perlunya penerapannya adalah untuk pencegahan dampak korupsi yang luar biasa hebat. Korupsi biasanya dilakukan dengan cara-cara yang sistematis dan terorganisir rapi, sehingga tidak hanya merugikan keuangan negara, itu dapat mengganggu stabilitas dan keamanan masyarakat, serta menodai norma-norma hukum, nilai kepatutan, kesejahteraan, keadilan sosial, dan juga merusak moral bangsa. Atas dasar itu dunia menamakan tindak pidana korupsi dengan extraordinary crimes (kejahatan yang luar biasa). Dan ulama fikih pun merumuskan kaidah asasi yang berkenaan dengan keharusan menghilangkan kemudharatan demi terwujudnya kemaslahatan, yaitu:

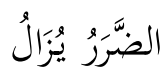

"Kemudharatan itu harus dihilangkan."

\section{Penutup}

Berdasarkan data-data yang telah disajikan dan dari hasil analisa data, maka dapat ditarik kesimpulan bahwa meski secara legal formal perbuatan melawan hukum materiil sudah tidak berlaku lagi dalam kebijakan hukum di Indonesia pasca keluarnya putusan Mahkamah Konstitusi RI. No. 003/PUU-IV/2006, namun dalam praktik peradilan tindak pidana korupsi, Pengadilan Negeri Kepanjen tetap menerapkan aturan perbuatan melawan hukum materiil. Adanya ketidak jelasan rumusan "sifat melawan hukum" yang disebabkan oleh kosongnya norma perbuatan melawan hukum materiil menyebabkan PN Kepanjen melakukan upaya penemuan hukum dengan penafsiran hukum dan juga ia merujuk kepada yurisprudensi dan doktrin yang ada tentang perbuatan melawan hukum materiil. Hal yang demikian dilakukan oleh PN Kepanjen tidak lain demi tegaknya keadilan.

Menurut hukum Islam, tindakan PN kepanjen yang tetap menerapkan aturan perbuatan melawan hukum materiil dengan cara melakukan penemuan hukum dan merujuk pada 
yurisprudensi adalah benar. Karena Islam juga mengajarkan untuk melakukan ijtihad ketika peraturan tidak mengatur tentang kasus yang diajukan kepada hakim untuk diselesaikan. Dalam hal ini metode yang tepat untuk digunakan berijtihad adalah 'urf. Dan ketika Hakim tidak bisa berijtihad, maka ia boleh merujuk kepada fatwa hakim yang terdahulu atau yurisprudensi. Penemuan hukum dan pengambilan yurisprudensi oleh PN Kepanjen tersebut bisa kita disebut sebagai sebuah tindakan penguatan ijtihad hakim yang terdahulu. Tampaknya aturan perbuatan melawan hukum materiil masih perlu untuk diterapkan dalam praktik peradilan pidana, khususnya dalam kasus korupsi. Hal yang demikian dimaksudkan untuk mencegah dan menghilangkan kemudharatan demi terwujudnya kemaslahatan.

\section{Daftar Pustaka}

Dahlan, Abd. Rahman. Ushul Figh. Jakarta: Amzah, 2010.

Dahlan, Abdul Aziz, et al. Ensiklopedi Hukum Islam. Jilid II, Jakarta: Ichtiar Baru Van Hoeve, 2003.

Fuady, Munir. Perbuatan Melawan Hukum Pendekatan Kontemporer. Bandung: PT Citra Aditya Bakti, 2005.

Kansil, C.S.T. Pengantar Ilmu Hukum. Jilid I, Jakarta: Balai Pustaka, 2002.

Kejaksaan Republik Indonesia. "Asas-asas Hukum Pidana". http://www.kejaksaan.go.id/pusdiklat/uplimg/File/Asasasas\%20Hukum\%20Pidana.doc diakses 31 Oktober 2013.

M.D., Moh. Mahfud. “Dilema Sifat Melawan Hukum (1) Kepastian Hukum atau Keadilan?". Jawa Pos, (08 September 2006).

--------. "Dilema Sifat Melawan Hukum (2-Habis) Kepastian Hukum Tabrak Keadilan". Jawa Pos, (09 September 2006).

Madkur, Muhammad Salam. Al-Qada' Fi al-Islam. Surabaya: Bina Ilmu, t.t.

Moeljatno. Asas-Asas Hukum Pidana. Jakarta: Rineka Cipta, 1993. 
Mubarok, Jaih. Kaidah Fiqh Jinayah Asas-asas Hukum Pidana Islam. Bandung: Pustaka Bani Quraisy, 2004.

Sabiq, Al Sayyid. Fiqhussunnah. Egypt: Dar Al-Fathi li Al-I'lamiAlAraby, 1990.

Tutik, Titik Triwulan. Konstruksi Hukum Tata Negara Indonesia Pasca Amandemen UUD 1945. Jakarta: Kencana, 2010.

UU No. 31 tahun 1999 Jo. UU No. 20 Tahun 2001.

Yayasan Penyelenggara Penterjemah/Penafsir Alquran. Alquran dan Terjemahnya. Jakarta: Yayasan Penyelenggara Penterjemah/Penafsir Alquran, 1971. 